\title{
Temporal and spatial variability of stream water chemistry on Subantarctic Marion Island
}

\author{
M.-J. Stowe ${ }^{1}$, David William Hedding ${ }^{2}$, Frank D. Eckardt ${ }^{1}$ \& Werner $\mathrm{Nel}^{3}$ \\ 'Department of Environmental and Geographical Science, University of Cape Town, Rondebosch, South Africa; \\ ${ }^{2}$ Department of Geography, University of South Africa, Florida, South Africa; \\ ${ }^{3}$ Department of Geography and Environmental Science, University of Fort Hare, Alice, South Africa
}

\begin{abstract}
Concentrations of major ions in stream water from the Soft Plume River on Subantarctic Marion Island were measured. During the annual relief voyage, samples were collected daily over a 16-day period (21 April-6 May 2015) from three sites along the stream to better understand temporal and spatial variability of stream water chemistry on the island. The chemical composition of the stream is dominated by the sea salts $\mathrm{Na}^{+}$and $\mathrm{Cl}^{-}$. Mean solute concentrations for $\mathrm{Na}^{+}$and $\mathrm{Cl}^{-}$are $7 \pm 0.58$ and $12.5 \pm 0.84 \mathrm{mg} / \mathrm{L}$, respectively. The mean molar $\mathrm{Na}$ : Cl ratio for all samples is $0.86 \pm 0.05$, with a range from 0.71 to $0.99(n=$ $47)$, and there is a strong, significant positive correlation between $\mathrm{Na}^{+}$and $\mathrm{Cl}^{-}$ concentrations $(r=0.80 ; p<0.001)$. These values are consistent with previous studies from Marion Island and other Subantarctic islands. Temporal variation in ion concentrations was small. The largest detected change was a decrease in most solute concentrations that coincided with two precipitation events. This decrease was largest at the highest altitude and the shallowest site, suggesting that there was more rainfall at this location. These findings confirm the dominance of the surrounding ocean as the main source of the island's stream water chemistry and illustrate spatiotemporal patterns that provide an insight into mechanisms affecting their composition on Subantarctic Marion Island.
\end{abstract}

\begin{abstract}
Keywords
Major ions; hydrochemistry; time series; freshwater; sea salts

Correspondence

M.-J. Stowe, Department of Environmental and Geographical Science, University of Cape Town, Private Bag X3, Rondebosch 7701, South Africa. E-mail: michaeljamesy@ gmail.com
\end{abstract}

\section{Abbreviations}

m a.m.s.l.: metres above mean sea level SPR: Soft Plume River

VDBR: Van Den Boogaard River

\section{Introduction}

Streams on remote and isolated maritime islands are strongly influenced by the surrounding ocean and, as a result, their major ion chemistry tends to be dominated by the sea salts (halite ions) $\mathrm{Na}^{+}$and $\mathrm{Cl}^{-}$(Gibbs 1970; Meurk et al. 1994; Soulsby 1995). Stream water chemistry on oceanic islands also reflects landscape position, watershed geomorphology, hydrogeological characteristics and biomass concentrations (Hodson et al. 2010; Welch et al. 2010; Lyons et al. 2013). Subsequently, elucidating specific processes and drivers regulating stream water chemistry can be challenging (Holloway \& Dahlgren 2001). In addition, processes that drive fluctuations in stream chemistry on islands are highly dynamic and spatially complex at hourly, daily, storm-event and seasonal time scales (Tomlinson \& De Carlo 2003; Freire et al. 2013).

Antarctica, the Subantarctic islands and the surrounding Southern Ocean-together regarded as one of the planet's last remaining wildernesses (Ansorge et al. 2017)_offer ideal environments for studying natural processes occurring in the mid-latitude environment (Stowe et al. 2018). Positioned at the interface between the Subantarctic Front and the Antarctic Polar Front in the Indian sector of the Southern Ocean, Subantarctic Marion Island is ideally placed to contribute to understanding environmental change in the Southern Hemisphere. Marion Island's freshwater chemistry has previously been discussed in detail by Grobbelaar (1974, 1975, 1978a, b), with more recent research expanding his initial findings (Smith 2008; van Staden 2011; Dartnall \& Smith 2012). Streams are characterized by an ionic dominance of $\mathrm{Na}^{+}$ $>\mathrm{Mg}^{2+}>\mathrm{Ca}^{+}>\mathrm{K}^{+}: \mathrm{Cl}^{-}>\mathrm{HCO}^{3-}>\mathrm{SO}_{4}^{2-}$ (Grobbelaar 1974, 1978a; van Staden 2011). The dominance of sea salts $\left(\mathrm{Na}^{+}\right.$and $\left.\mathrm{Cl}^{-}\right)$reflect the island's maritime and latitudinal position. According to Grobbelaar (1978), the island's stream water chemistry is predominantly controlled by the high amounts of rainfall throughout the year and enrichment from nutrients in aerosols blown in from the sea (Smith \& Froneman 2008). The dominance of westerly and north-westerly winds force substantial amounts of sea-salt particles into the atmosphere, which is then 
often deposited as sea spray and condensation nuclei in raindrops on the terrestrial environment (Schulze 1971; Rouault et al. 2005). Together, these factors exhibit variable influence on stream water chemistry depending on the prevailing climatic conditions and landscape position of the stream (Grobbelaar 1975).

Higher temporal resolution investigations into stream water chemistry on the island are rare. Grobbelaar (1974) provided the only continuous, daily time series of stream water chemistry. Samples were taken from six locations along the VDBR (Fig. 1b) and also over a 27-day period (8 February - 5 March 1972) at a single site, approximately at $250 \mathrm{~m}$ a.m.s.l. The VDBR is a major stream situated on young black basaltic lava on the eastern side of the island, similar to that of the SPR (Fig. lb). The VDBR has been dammed to provide the research station with water. This has altered stream flow dynamics below the dam, and the VDBR has been observed to run dry near the coast during prolonged dry spells (Hedding, pers. obs.). Grobbelaar
(1974) showed that sea salts were the most abundant at all sites, with a small increase in ionic content along the course of the river. Temporal variation in stream $\mathrm{Na}^{+}$and $\mathrm{Cl}^{-}$concentrations were observed through the time series. Strong negative correlations were found between the amount of daily rainfall and $\mathrm{Na}^{+}(r=-0.74)$ and $\mathrm{Cl}^{-}(r=-0.54)$ in streams, suggesting that the amount of rainfall has a significant influence on stream chemistry (Grobbelaar 1974). However, precipitation on Subantarctic Marion Island has decreased significantly since the 1960s from an annual average of $2727 \mathrm{~mm}$ in the 1960s to $1778 \mathrm{~mm}$ in the decade preceding 2016 (Hedding \& Greve 2018). To expand on this information, concentrations of major ions in the SPR on Subantarctic Marion Island were measured with greater frequency. Samples were collected daily over a 16-day period (21 April-6 May 2015) from three sites along the stream to better understand the temporal and spatial variability of stream water chemistry on the island. The purpose of the research is to evaluate the influence of sea spray and

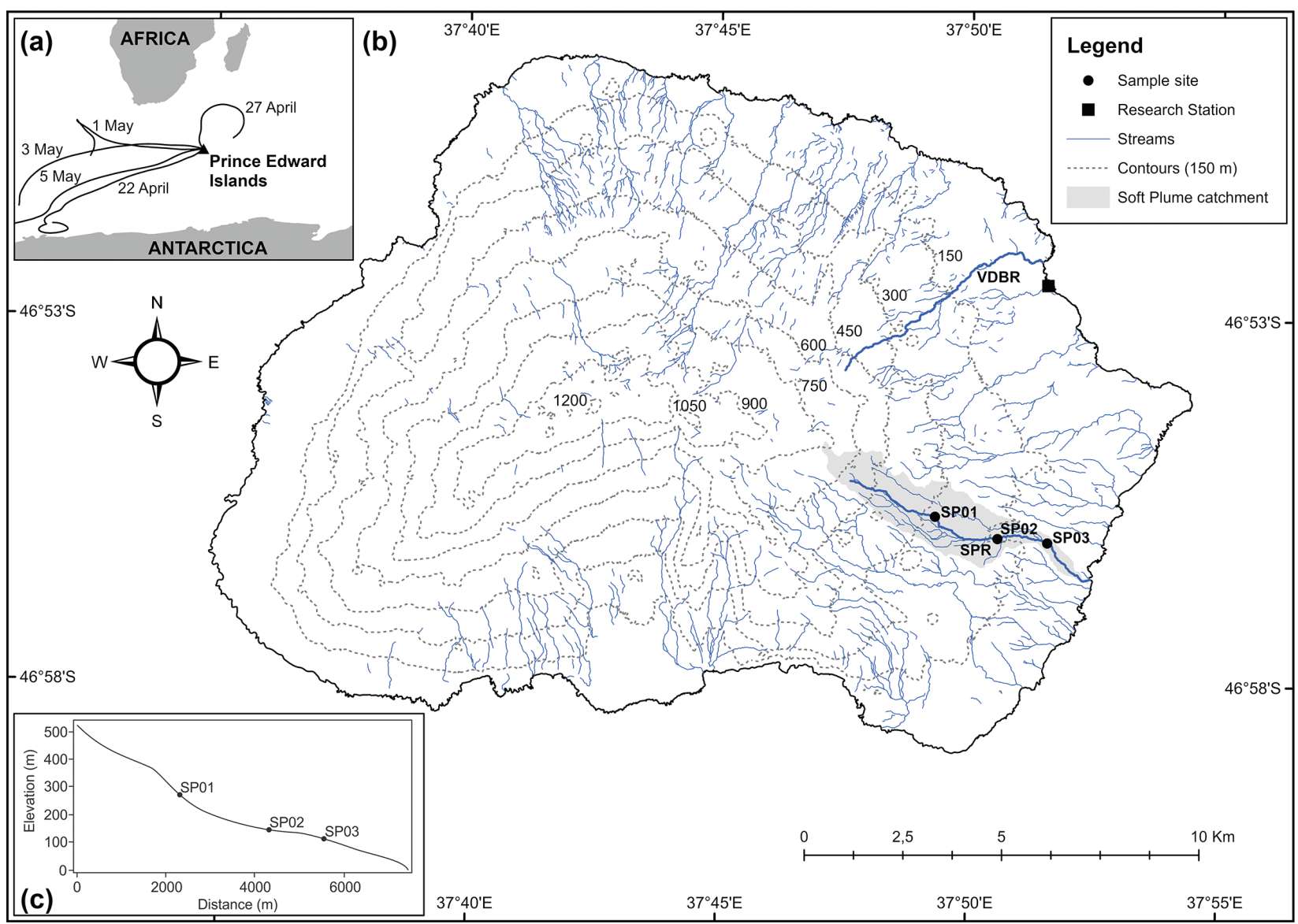

Fig. 1 (a) Location of Prince Edward Islands in relation to major landmasses. Back trajectories (96 hours) on 22 April (18:00 GMT +3), 27 April (06:00 GMT +3), 1 May (06:00 GMT +3), 3 May (18:00 GMT +3) and 5 May (18:00 GMT +3). (b) Map of Marion Island, indicating sampling sites in the SPR catchment. (c) Elevation profile of the sampling sites. 
chemical weathering on stream water chemistry on Subantarctic Marion Island.

\section{Study area}

\section{Regional setting}

Marion Island $\left(46^{\circ} 54^{\prime} \mathrm{S}\right.$ and $\left.37^{\circ} 5 \mathrm{l}^{\prime} \mathrm{E}\right)$ is the tip of an intraplate shield volcano (McDougall et al. 2001) and is the larger of the two islands that comprise the Prince Edward Islands group. The island has an area of $293 \mathrm{~km}^{2}$ (Hedding 2008) and is located in the Indian Ocean sector of the Southern Ocean, some $2000 \mathrm{~km}$ south-east of South Africa (Fig. la; Lutjeharms \& Ansorge 2008). Its geographic position in the "Roaring Forties" results in a hyper-oceanic climate regime (Boelhouwers et al. 2003; Le Roux \& McGeoch 2008). The synoptic climate of the island is characterized by a sequence of mid-latitude depressions, the passage of frontal systems from the west and the influence of anticyclones (Vowinckel 1954; Le Roux 2008). Mid-latitude depressions (cyclones) are initiated somewhere in the Atlantic Ocean between latitude $30^{\circ}$ and $40^{\circ} \mathrm{S}$ (Schulze 1971), and an approaching cold front is associated with a strengthening of the north-westerly winds, an influx of warm subtropical air and an increase in cloudiness (Tyson $\&$ Preston-Whyte 2000). Meteorological observations at the research station on the eastern coast of the island indicate that winds mostly originate from a westerly to north-westerly direction, which is related to the predominant synoptic conditions (Le Roux 2008; Nel et al. 2009; Nel 2012). Winds measured $5 \mathrm{~m}$ above the ground at the research station are generally very strong, with an average daily velocity of $8.4 \mathrm{~m} / \mathrm{s}$ (Hedding et al. 2015). Intense and prolonged island-wide precipitation is closely associated with pre-frontal conditions of mid-latitudinal cyclones. Mean annual air temperature is $5.9^{\circ} \mathrm{C}$ but sub-zero temperatures can also be experienced throughout the year. The island's synoptic climate also drives diurnal frost processes that are currently the dominant geomorphic process on the island (Nel et al. 2009).

Geologically, the island is composed of an older sequence of pre-glacial (Pleistocene) grey basalt basement where the earliest subaerial eruptions took place at least $450000 \mathrm{BP}$ (McDougall et al. 2001) and extensive younger (Holocene) black lava flows and scoria cones that post-date the Last Glacial Maximum. According to McDougall et al. (2001), all the lava on the island belong to an alkaline oceanic island basalt suite with $\mathrm{SiO}_{2}$ ranging between 45 and $55 \%$. The geological substratum plays a significant role in determining the composition and complexity of flora (Gremmen \& Smith 2008). Although the island may appear bleak and barren, below $600 \mathrm{~m}$ a.m.s.l. there is a dense and often complex vegetation consisting of a variety of plant communities (Gremmen $\&$ Smith 2008).

\section{Study site}

The SPR is the longest perennial stream on the island and is found in the south-east quadrant of the island (Fig. lb). The SPR provides an opportunity to investigate temporal and spatial stream chemical dynamics of the only continuously flowing lotic water on the island. In addition, no continuous and systematic study of the SPR has previously been carried out. To address this knowledge gap, three locations along the SPR were identified to better understand spatial and temporal stream dynamics. The three study sites span an altitudinal range of about 150 $\mathrm{m}$. The highest site, SP01 is at ca. $253 \mathrm{~m}$ a.m.s.l., while the lower sites SP02 and SP03 are located at about 179 and about 103 m a.m.s.l., respectively (Fig. 1c).

\section{Methods}

\section{Sample collection}

A total of 47 samples were collected from three sites along the SPR (Fig. 1; SP01, SP02 SP03) over an intense 16-day field campaign (21 April-6 May 2015) during the annual relief voyage. Sampling was carried out daily at approximately the same time (ca. 10:00 GMT +3, SP01; ca. 10:30 GMT +3, SP02; ca. 11:00 GMT +3, SP03) to ensure that any diurnal variation in solute concentrations were evenly accounted for (Neal et al. 2012). All samples were collected in $250 \mathrm{ml}$ polyethylene bottles. Prior to departure into the field, sample bottles were acidwashed with diluted $\mathrm{HNO}_{3}$ and rinsed three times with distilled-deionized water. Sample water was filtered on site using cellulose acetate $0.45 \mu \mathrm{m}$ membrane syringe filters. Given the low ambient temperatures present on the island, no preservative was added to the filtered sample (Grobbelaar 1978a). All water samples were stored for the duration of the study at $4^{\circ} \mathrm{C}$ at the research station on Marion Island.

\section{Sample analysis}

The cations $\left(\mathrm{Ca}^{2+}, \mathrm{Mg}^{2+}, \mathrm{K}^{+}, \mathrm{Na}^{+}\right)$were analysed by inductively coupled plasma-atomic emission spectrometry (Thermo ICap 6200). The instrument was calibrated using National Institute of Standards and Technology (Gaithersburg MD, USA) traceable standards to quantify the cations. The analytical precision was within 10\%: 94.3\% for $\mathrm{Ca}, 96.7 \%$ for $\mathrm{Mg}, 96.5 \%$ for $\mathrm{K}$ and $99.2 \%$ for $\mathrm{Na}$. Anions $\left(\mathrm{Cl}^{-}, \mathrm{SO}_{4}{ }^{2-}\right)$ were analysed by ion chromatography with 
a Waters IC Pak Anion column (4.5 mm $\times 50 \mathrm{~mm}$ ) and a Waters 432 Conductivity detector, coupled to a Waters 717plus Auto sampler and an Agilent 1100 series binary pump. The gradient pump flow rate was set at $1.1 \mathrm{ml} /$ min. Precision of the anion measurements was $<5 \%$ based on the average per cent difference between duplicate analyses of the samples.

\section{Data}

Hourly precipitation $(\mathrm{mm})$ data recorded at the research station (Fig. 2) were obtained from the South African Weather Service. Backward trajectories (96 hours) were generated using National Oceanic and Atmospheric Administration Hybrid Single-Particle Lagrangian Integrated Trajectory model (Stein et al. 2015) runs for 22 April (18:00), 27 April (06:00), 1 May (06:00), 3 May (18:00) and 5 May (18:00) coinciding with the major rain events observed in the catchment.

To examine the influence of seawater and precipitation inputs on stream water, we determined enrichment factors for each sample. Assuming that $\mathrm{Cl}$ is entirely marine derived, we obtained enrichment factors relative to $\mathrm{Cl}$ by obtaining ionic ratios for water samples (sample $\mathrm{x} / \mathrm{Cl})$ and dividing these by relative elemental composition of seawater for Ca (0.021), Mg (0.067), K (0.021), Na (0.55) and $\mathrm{SO}_{4}$ (0.14) (Kennish 1989). The $\mathrm{HCO}_{3}^{-}$concentrations in these samples were estimated by charge balance differences between the Ecations in equivalents minus the Sanion equivalents. All data were collated, analysed and plotted using $\mathrm{R}$ statistical software version 3.3.0 (R Core Team 2016).

\section{Results}

\section{Chemical characteristics of the SPR}

Summary statistics of stream water chemistry data from the SPR are presented in Table 1. The mean molar $\mathrm{Na}$ :Cl ratio for all samples is $0.86 \pm 0.05$, with a range from 0.71 to $0.99(n=47)$. There is a strong, significant positive correlation between $\mathrm{Na}^{+}$and $\mathrm{Cl}^{-}$concentrations $(r=0.80 ; p<0.001)$. Average concentrations of other major ions such as $\mathrm{Ca}^{2+}, \mathrm{Mg}^{2+}, \mathrm{K}^{+}$and $\mathrm{SO}_{4}{ }^{2-}$ show moderate to high correlation with $\mathrm{Cl}^{-}(r=0.48, r=0.67$, $r=0.37$ and $r=0.22$, respectively). The estimated alkalinity concentrations ranged from 0.72 to $8.17 \mathrm{mg} / \mathrm{L}$, with a mean of $5.6 \pm 1.78 \mathrm{mg} / \mathrm{L}(n=37)$. While estimated alkalinity values are greater than those observed by Grobbelaar (1978b) for different lakes around the island, the values corroborate observations of higher $\mathrm{HCO}_{3}{ }^{-}$concentrations for flowing waters on the island (Grobbelaar 1978a).
The mean enrichment factors for each analyte are shown in Table 2. The backward trajectories (Fig. la) and Global Data Assimilation System archive data, at $500 \mathrm{~m}$ a.m.s.l., suggest that the airmasses largely originated from the south-west Atlantic (Fig. la).

\section{Temporal variation}

A daily time series of solute concentrations is presented in Fig. 2. Low amplitude diurnal variation is observed at all sites. Superimposed on the diurnal variation are two distinct dips in the concentrations of all ions, except for $\mathrm{SO}_{4}{ }^{2-}$, on 23 April and 4 May 2015, respectively (Fig. 2). These two decreases in solute concentrations coincide with rainfall events on 22 April 2015 and 3-4 May 2015 (see Fig. 2a-g). The two rainfall events were associated with mid-latitude cyclones that resulted in rainfall amounting to $14.2 \mathrm{~mm}$ (22 April, 12:00-21:00 GMT+3) and $11.8 \mathrm{~mm}$ (3 May, 20:00 GMT +3 to 04:00 GMT +3, 4 May 2015) recorded at the research station (Fig. 1b).

\section{Variation along the stream}

The ionic composition of the SPR exhibited identifiable and, in some cases, significant differences between SP01, SP02 and SP03 for each ion, respectively (Fig. 3; Table 3). For all solutes except $\mathrm{SO}_{4}{ }^{2-}$, total variation is largest at SP01 (Fig. 3). $\mathrm{SO}_{4}{ }^{2-}$ concentrations exhibited a similar degree of variation at all three sites (Fig. 3f). Total variation in solute concentrations at SP02 is generally similar to that at SP03. Significantly lower concentrations of $\mathrm{K}^{+}$, $\mathrm{Na}^{+}$and $\mathrm{Cl}^{-}$were found at SP0 1 compared with the lower altitude sites SP02 and SP03 (Table 3). No significant differences were found for the rest of the solutes between any of the sampling sites (Table 3).

\section{Discussion}

\section{Chemical composition of the SPR}

While stream water chemistry can vary considerably, the major mechanisms controlling composition have been identified broadly as atmospheric precipitation, bedrock mineralogical and geochemical characteristics and evaporation-crystallization processes (Clarke 1924; Gibbs 1970). On oceanic islands, freshwaters receive most of their ions from precipitation (Tyler 1972; Buckney \& Tyler 1974). This results in the chemical composition of freshwater closely resembling that of sea water (Gorham \& Cragg 1960). Concentrations of major ions in the SPR highlight the substantial influence Marion Island's hyper-maritime location and associated 


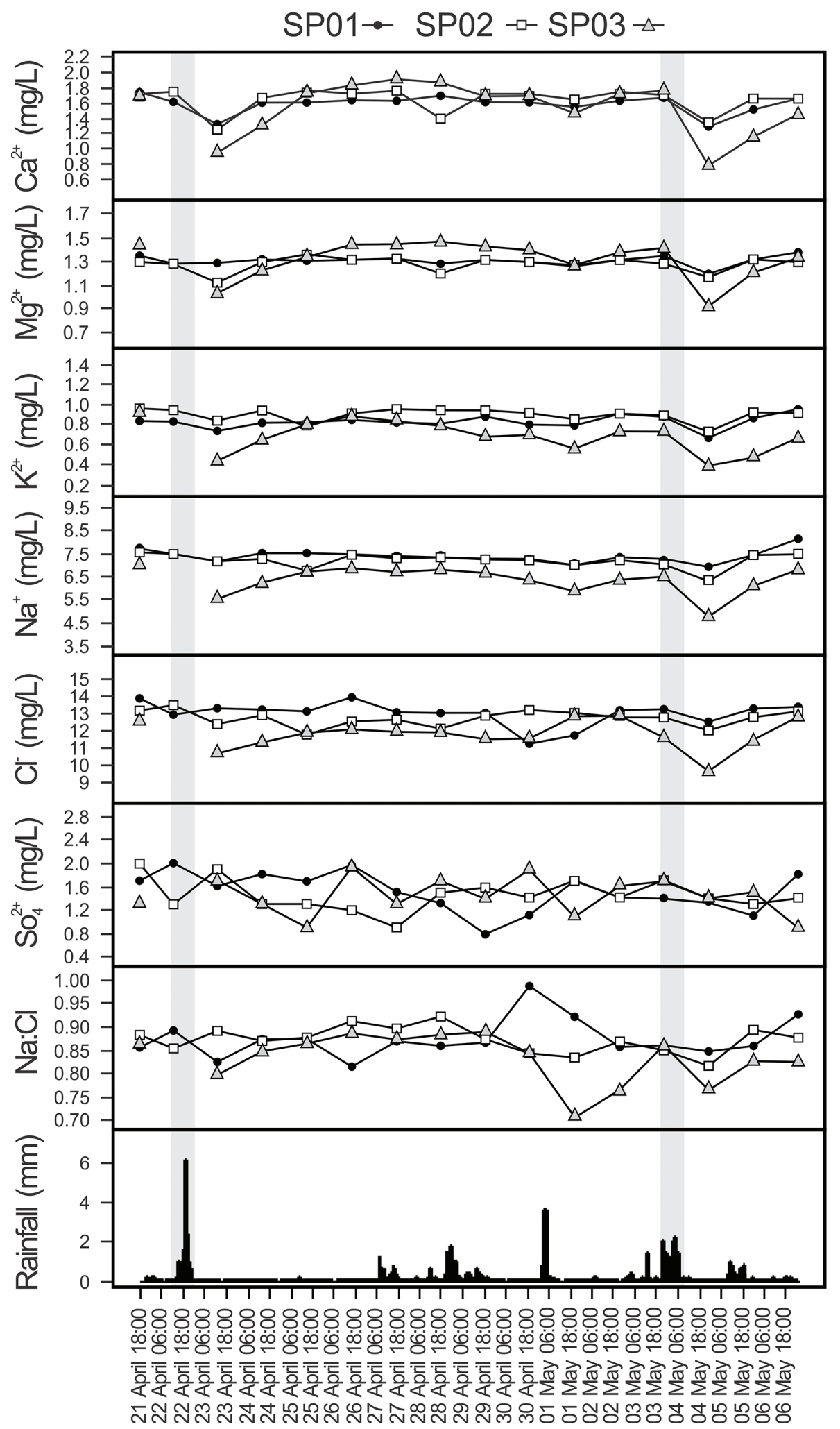

(a)

(b)

(c)

(d)

(e)

(f)

(g)

(h)

Fig. 2 Time series of (a) $\mathrm{Ca}^{2+}$, (b) $\mathrm{Mg}^{2+}$, (c) $\mathrm{K}^{+}$, (d) $\mathrm{Na}^{+}$, (e) $\mathrm{Cl}^{-}$, (f) $\mathrm{SO}_{4}{ }_{4}^{2-}$ and (g) $\mathrm{Na}: \mathrm{Cl}$ ratio over the period 21 April -6 May 2015, measured at SP01, SP02 and SP03 along the SPR. Vertical grey bars indicate the duration of rainfall between 12:00 and 21:00 GMT + 3 on 22 April 2015 (14.4 mm) and 20:00 GMT +3 on 3 May 2015 to 04:00 GMT +3 on 4 May 2015 (11.8 mm), respectively. 
Table 1 Summary statistics of solute concentrations (mg/L) measured at sites SP01, SP02 and SP03 along the SPR.

\begin{tabular}{llccccc}
\hline Solute & $N^{a}$ & Mean & SD $^{b}(1 \sigma)$ & Min & Max & Range \\
\hline $\mathrm{Ca}^{2+}$ & 47 & 1.58 & 0.22 & 0.79 & 1.91 & 1.12 \\
$\mathrm{Mg}^{2+}$ & 47 & 1.3 & 0.1 & 0.91 & 1.48 & 0.57 \\
$\mathrm{~K}^{+}$ & 47 & 0.81 & 0.13 & 0.39 & 0.97 & 0.58 \\
$\mathrm{Na}^{+}$ & 47 & 6.99 & 0.58 & 4.84 & 8.05 & 3.21 \\
$\mathrm{Cl}^{-}$ & 47 & 12.49 & 0.84 & 9.7 & 13.8 & 4.1 \\
$\mathrm{SO}_{4}{ }^{2-}$ & 47 & 1.47 & 0.31 & 0.8 & 2 & 1.2 \\
\hline
\end{tabular}

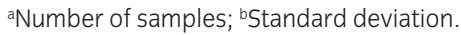

Table 2 Mean enrichment factors of major ions in stream water from the SPR.

\begin{tabular}{lllllll}
\hline Site & $\mathrm{N}^{\mathrm{a}}$ & $\mathrm{Ca}^{2+}$ & $\mathrm{Mg}^{2+}$ & $\mathrm{K}^{+}$ & $\mathrm{Na}^{+}$ & $\mathrm{SO}_{4}^{2-}$ \\
\hline SP01 & 47 & 5.9 & 1.0 & 4.9 & 1.0 & 0.1 \\
SP02 & 47 & 6.3 & 1.0 & 5.1 & 1.0 & 0.1 \\
SP03 & 47 & 5.7 & 0.9 & 4.9 & 1.0 & 0.1 \\
\hline
\end{tabular}

${ }^{a}$ Number of samples.

climatic conditions have on its stream water chemical composition.

Consistent with previous studies, ion concentrations in the SPR were low with the same relative proportions as that of seawater (Grobbelaar 1974, 1975, 1978a; van Staden 2011). $\mathrm{Na}^{+}$and $\mathrm{Cl}^{-}$were most abundant in the SPR, with mean concentrations of $7 \pm 0.58 \mathrm{mg} / \mathrm{L}$ and $12.5 \pm 0.84$ $\mathrm{mg} / \mathrm{L}$, respectively. There was a strong, positive relationship $(r=0.80 ; p<0.001)$ between them. The mean molar Na:Cl ratio $(0.86)$ is virtually the same as that of seawater $(0.87$; Likens et al. 1987). On islands and in coastal regions, $\mathrm{Na}: \mathrm{Cl}$ ratios (see Fig. 2) of this order indicate that atmospheric inputs, enriched in sea salts derived from the surrounding ocean, are the dominant control on precipitation and surface water chemistry (Gaillardet et al. 1999; McNeil et al. 2005). This is further supported by the similarity between SPR chemistry and rainfall chemistry measured at the meteorological station on Marion Island, with $\mathrm{Na}^{+}$and $\mathrm{Cl}^{-}$being the most abundant ions (Grobbelaar 1974; Smith 1987).

These findings are in agreement with studies from other Subantarctic islands. For example, on Macquarie Island, Iles Kerguelen and Subantarctic Campbell Island, the chemical composition of freshwater is dominated by $\mathrm{Na}^{+}$and $\mathrm{Cl}^{-}$, with the authors attributing the abundance of these ions to the influence of the ocean surrounding the respective islands (Tyler 1972; Taylor 1974). Studies from maritime Antarctica also found a similar pattern. $\mathrm{Na}^{+}$ and $\mathrm{Cl}^{-}$were the most abundant ions in the freshwaters on Signy Island (Caulkett \& Ellis-Evans 1997), Livingston Island (Toro et al. 2007) and King George Island (Vinocur \& Unrein 2000). Nędzarek et al. (2015) concluded that this pattern is typical for small streams on oceanic islands that have relatively damp climates.

\section{Temporal and spatial variability}

Stream solute concentrations have been shown to vary on different temporal scales (Neal \& Kirchner 2000; Kirchner et al. 2004; Neal et al. 2012). Daily sampling of the SPR revealed that solute concentrations remained relatively stable over the study period (Fig. 2). The largest variation was characterized by a decrease in most solutes, which coincided with higher rainfall amounts on 22 April 2015 (14.2 mm) and 3-4 May 2015 (11.8 mm), respectively (Fig. 2). The rainfall events resulted in the dilution of solute concentrations. Similarly, Lee et al. (2015) found a response from solutes in the Haean Basin, between South Korea and North Korea, whereby dilution of stream ions varied relative to rainfall intensity, duration and antecedent moisture conditions. Furthermore, the uniform response of most solutes at different sites over the time series, in particular $\mathrm{Na}^{+}$and $\mathrm{Cl}^{-}$, indicates that variation in solute concentrations is predominantly controlled by rainfall inputs (Neal et al. 2012).

Although the three sampling sites lie within about $3 \mathrm{~km}$ of each other and drain a common lithology, spatial differences in stream chemistry were observed. Variation along the stream was strongly influenced by precipitation and depth differences at various stages along the course of the stream. For most solutes, the largest amount of variation occurs at SP01, the highest altitude and the shallowest sampling location (Fig. 3). $\mathrm{Na}^{+}$and $\mathrm{Cl}^{-}$values were significantly lower at SP01 than at SP02 and SP03 (Table 3). It is likely that an altitudinal precipitation gradient, coupled with the shallowness of the stream, contributed to the amount of variation, with more rainfall and subsequently lower solute concentrations occurring at SP01. This finding is supported by Stowe et al. (2018), who observed higher total daily rainfall amounts further up the SPR catchment compared with a lower site. Altitudinal rainfall gradients have also been observed elsewhere on the island over longer time periods. Blake (1996) found total annual rainfall at mid-altitude (4653 $\mathrm{mm}$, ca. $550 \mathrm{~m}$ a.m.s.l.) to be higher than a lower elevation site (2873 mm, $34 \mathrm{~m}$ a.m.s.l.). However, direct precipitation measurements along the course of the stream that cover seasonal and inter-annual hydro-climatic variability are needed to assess the impact of rainfall on the variation of ion concentrations.

\section{Comparison between streams on the island}

$\mathrm{Na}^{+}$and $\mathrm{Cl}^{-}$values are significantly lower at SP01 than at SP02 and SP03 (Table 3). This inverse relationship between solute concentrations and distance from the 


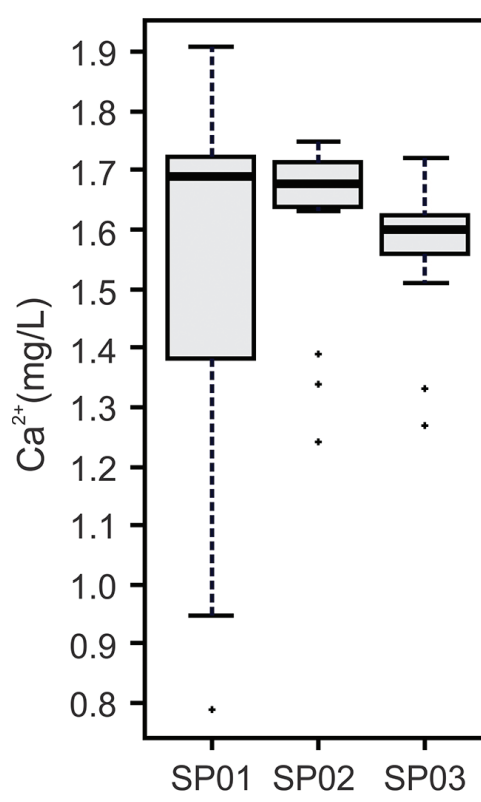

(a)
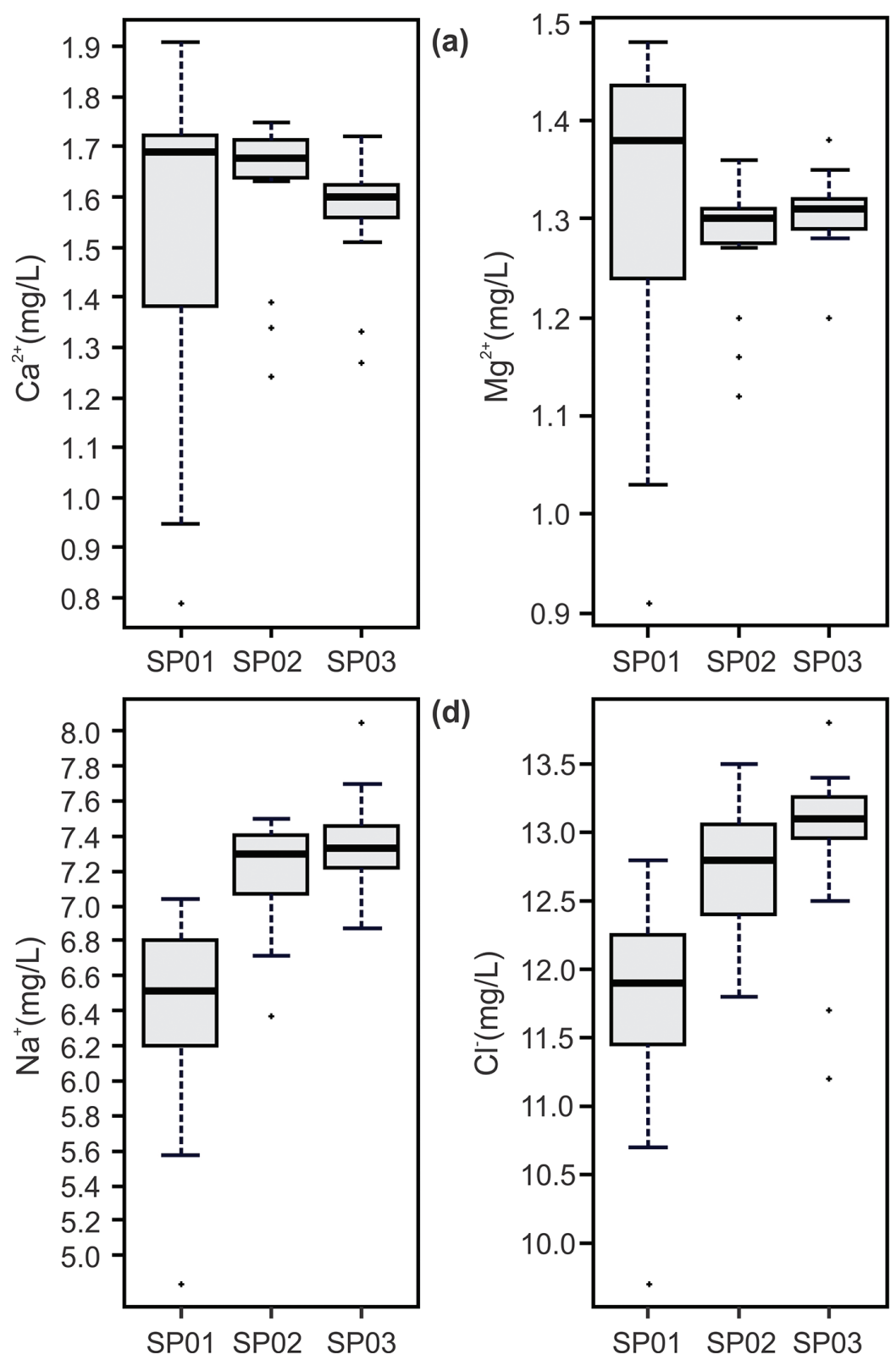

(b)

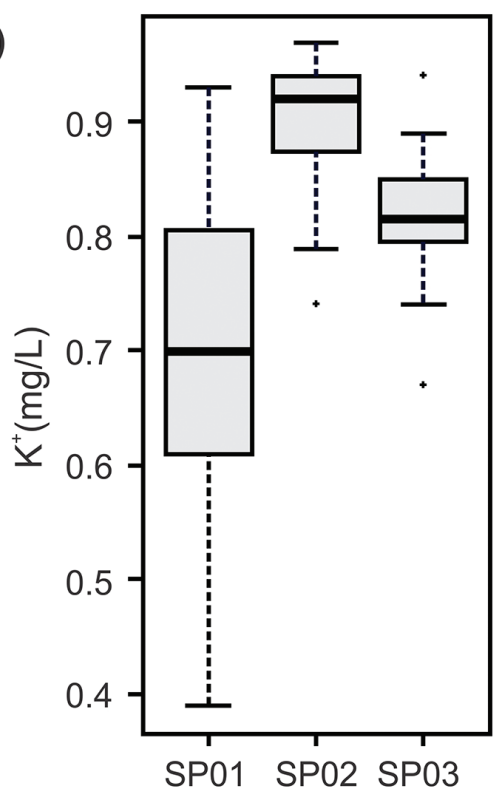

(c)

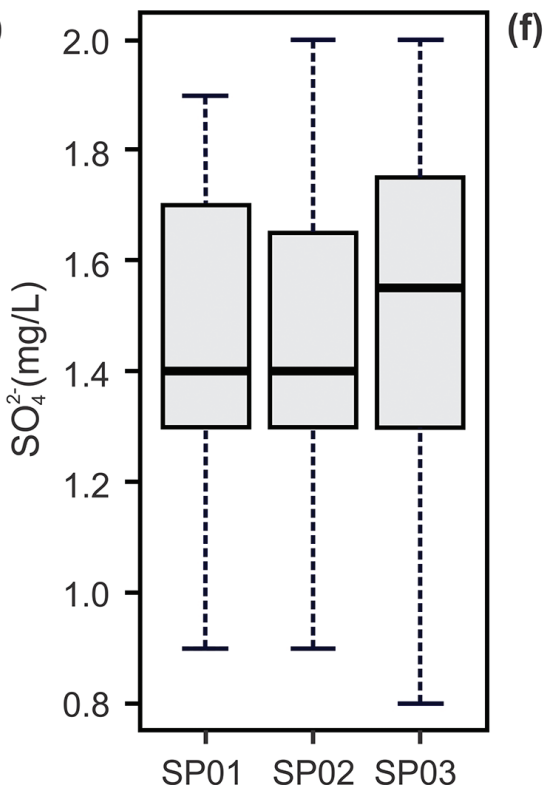

Fig. 3 Box and whisker plots for all major ions sampled along the SPR at SP01, SP02 and SP03, respectively, where (a) $\mathrm{Ca}^{2+}$, (b) $\mathrm{Mg}^{2+}$, (c) $\mathrm{K}^{+}$, (d) $\mathrm{Na}^{+}$, (e) $\mathrm{Cl}^{-}$ and (f) $\mathrm{SO}_{4}{ }^{2-}$. The boxes are bounded by lower and upper quartile limits, with the central line within the box representing the median values. The whiskers extend to the most extreme values within 1.5 times the interquartile range. Outliers are displayed by crosses.

coast has been observed elsewhere on oceanic islands (Caulkett \& Ellis-Evans 1997) and coastal sites (Neal \& Kirchner 2000; McNeil et al. 2005). Although only based on a single day of sampling (31 January 1972), Grobbelaar (1974) found a similar altitudinal relationship for $\mathrm{Na}^{+}$and $\mathrm{Cl}^{-}$along the VDBR, where the lowest concentration of stream $\mathrm{Na}^{+}$and $\mathrm{Cl}^{-}$was found at the highest site (ca. $350 \mathrm{~m}$ a.m.s.l.) and gradually increased downstream.

\section{Conclusion}

Our findings are consistent with results from previous studies on Subantarctic Marion Island and other small mid-latitude islands. The dominance of sea salts and the mean Na:Cl ratio (0.86) were nearly identical to that of seawater (0.87), indicating that precipitation enriched by marine ions controls the chemical composition of the SPR. Geographic conditions determine the proportions of 
Table 3 Wilcoxon signed-rank test results for differences in major ions between sampling sites SP01, SP02 and SP03. Values of $p$ represent the probability that the two data sets are derived from the same distribution. Significantly different values are in boldface.

\begin{tabular}{|c|c|c|c|}
\hline \multirow[t]{2}{*}{ Ion } & SP01-SP02 & SP01-SP03 & SP02-SP03 \\
\hline & $p$ & $p$ & $p$ \\
\hline$\overline{\mathrm{Ca}}{ }^{2+}$ & 0.38 & 0.84 & 0.20 \\
\hline $\mathrm{Mg}^{2+}$ & 0.05 & 0.55 & 0.18 \\
\hline $\mathrm{K}^{+}$ & $<0.001$ & $<0.05$ & $<0.001$ \\
\hline $\mathrm{Na}^{+}$ & 0.11 & $<0.0001$ & $<0.001$ \\
\hline $\mathrm{Cl}^{-}$ & 0.15 & $<0.005$ & $<0.05$ \\
\hline $\mathrm{SO}_{4}{ }^{2-}$ & 0.5 & 0.78 & 0.81 \\
\hline
\end{tabular}

major ions in the SPR, although the amount of rainfall, which drives stage-flow fluctuations along with stream geomorphology, influences variability and the overall concentration. The greater variability of ion concentrations at SP01 is probably the result of topographically induced rainfall falling in larger amounts higher up in the SPR catchment, coupled with the shallowness of the stream at this site. Together, these data provide new insights into the spatiotemporal variability of stream water chemistry on Subantarctic Marion Island.

\section{Acknowledgements}

This research received logistical support from the South African Department of Environmental Affairs. Climate data from the research station on Marion Island were provided by the South African Weather Service. Abuyiselwe Nguna (University of Fort Hare, South Africa) assisted with sample collection in the field. Riana Rossouw and Meryl Patience of the Central Analytical Facility at Stellenbosch University, South Africa, analysed major cations and anions, respectively.

\section{Funding}

The research presented here is part of the project Landscape and Climate Interactions in the Sub-Antarctic (grant no. 110723). Funding was provided through the National Research Foundation, by the South African Department of Science and Technology under the auspices of the South African National Antarctic Programme.

\section{Disclosure statement}

The authors report no conflict of interest.

\section{References}

Ansorge I., Skelton P., Bekker A., de Bruyn P.J.N., Butterworth D., Cilliers P., Cooper J., Cowan D.A., Dorrington R., Fawcett S., Fietz S., Findlay K.P., Froneman P.W., Grantham G.H., Greve M., Hedding D.W., Hofmeyr G.J.G, Kosch M., Le Roux P.C., Lucas M., MacHutchon K., Meiklejohn K.I., Nel W., Pistorius P., Ryan P.G., Stander J., Swart S., Treasure A., Vichi M. \& Jansen van Vuuren B. 2017. Exploring South Africa's southern frontier: a 20-year vision for polar research through the South African National Antarctic Programme. South African Journal of Science 113, a0205, doi: 10.17159/sajs.2017/a0205.

Blake B.J. 1996. Microclimate and prediction of photosynthesis at Marion Island. MSc dissertation, University of the Free State, Bloemfontein.

Boelhouwers J., Holness S. \& Sumner P. 2003. The maritime Subantarctic: a distinct periglacial environment. Geomorphology 52, 39-55, doi: 10.1016/S0169-555X(02)00247-7.

Buckney R.T. \& Tyler P.A. 1974. Reconnaissance limnology of sub-Antarctic islands. II. Additional features of the chemistry of Macquarie Island lakes and tarns. Australian Journal of Marine and Freshwater Research 25, 89-95.

Caulkett A.P. \& Ellis-Evans J.C. 1997. Chemistry of streams of Signy Island, maritime Antarctic: sources of major ions. Antarctic Science 9, 3-11, doi: 10.1017/S0954102097000023.

Clarke F.W. 1924. The data of geochemistry. United States Geological Survey Bulletin 770. 5th edn. Washington, DC: Government Printing Office.

Dartnall H.J. \& Smith V.R. 2012. Freshwater invertebrates of sub-Antarctic Marion Island. African Zoology 47, 203-215, doi: 10.1080/15627020.2012.11407548.

Freire P., Andrade C., Coutinho R. \& Cruz J.V. 2013. Fluvial geochemistry in São Miguel Island (Azores, Portugal): source and fluxes of inorganic solutes in an active volcanic environment. Science of the Total Environment 454/455, 154-169, doi: 10.1016/j.scitotenv.2013.02.090.

Gaillardet J., Dupré B. \& Allègre C.J. 1999. Geochemistry of large river suspended sediments: silicate weathering or recycling tracer? Geochimica et Cosmochimica Acta 63, 4037-4051, doi: 10.1016/S0016-7037(99)00307-5.

Gibbs R.J. 1970. Mechanisms controlling world water chemistry. Science 170, 1088-1091, doi: 10.1126/science.170.3962.1088.

Gorham E. \& Cragg J.B. 1960. The chemical composition of some bog waters from the Falkland Islands. Journal of Ecology 48, 175-181, doi: 10.2307/2257316.

Gremmen N.J.M. 1981. The vegetation of the Subantarctic islands Marion and Prince Edward Geobotany 3. The Hague: Dr W. Junk Publishers.

Gremmen N.J.M. \& Smith V.R. 2008. Terrestrial vegetation and dynamics. In S.L. Chown \& P.W. Froneman (eds.): The Prince Edward Islands: land-sea interactions in a changing ecosystem. Pp. 215-244. Stellenbosch: Sun Press.

Grobbelaar J.U. 1974. A contribution to the limnology of the sub-Antarctic island Marion. PhD thesis, University of the Orange Free State, Bloemfontein.

Grobbelaar J.U. 1975. The lentic and lotic freshwater types of Marion Island (sub-Antarctic): a limnological study. 
Verhandlungen Internationale Vereinigung Limnologie 19, 949-951, doi: 10.1080/03680770.1974.11896202.

Grobbelaar J.U. 1978a. Mechanisms controlling the composition of fresh waters on the sub-Antarctic island Marion. Archiv für Hydrobiologie 83, 145-157.

Grobbelaar J.U. 1978b. Factors limiting the algal growth on the sub-Antarctic island Marion. Verhandlungen Internationale Vereinigung für Limnologie 20, 1159-1164, doi: 10.1080/03680770.1977.11896666.

Hedding D.W. 2008. Spatial inventory of landforms in the recently exposed central highland of sub-Antarctic Marion Island. South African Geographical Journal 90, 11-21, doi: 10.1080/03736245.2008.9725307.

Hedding D.W. \& Greve M. 2018. Decreases in precipitation on sub-Antarctic Marion Island: implications for ecological and geomorphological processes. Weather 73, article no. 203, doi: 10.1002/wea.3245.

Hedding D.W., Nel W. \& Anderson R.L. 2015. Aeolian processes and landforms in the sub-Antarctic: preliminary observations from Marion Island. Polar Research 34, article no. 26365, doi: 10.3402/polar.v34.26365.

Hodson A., Heaton T., Langford H. \& Newsham K. 2010. Chemical weathering and solute export by meltwater in a maritime Antarctic glacier basin. Biogeochemistry 98, 9-27, doi: 10.1007/s10533-009-9372-2.

Holloway J.M. \& Dahlgren R.A. 2001. Seasonal and eventscale variations in solute chemistry for four Sierra Nevada catchments. Journal of Hydrology 250, 106-121, doi: 10.1016/S0022-1694(01)00424-3.

Kennish M.J. 1989. Practical handbook of marine science. Section 2. Chemical oceanography. Boca Raton, FL: CRC Press.

Kirchner J.W., Feng X., Neal C. \& Robson A.J. 2004. The fine structure of water-quality dynamics: the (high-frequency) wave of the future. Hydrological Processes 18, 1353-1359, doi: 10.1002/hyp. 5537.

Le Roux P.C. 2008. Climate and climate change. In S.L. Chown \& P.W. Froneman (eds.): The Prince Edward Islands: land-sea interactions in a changing ecosystem. Pp. 39-64. Stellenbosch: Sun Press.

Le Roux P.C. \& McGeoch M.A. 2008. Changes in climate extremes, variability and signature on sub-Antarctic Marion Island. Climatic Change 86, 309-329, doi: 10.1007/ s10584-007-9259-y.

Lee H.-J., Chun K-W., Shope C.L. \& Park J.-H. 2015. Multiple time-scale monitoring to address dynamic seasonality and storm pulses of stream water quality in mountainous watersheds. Water 7, 6117-6138, doi: 10.3390/W7116117.

Likens G.E., Keene W.C., Miller J.M. \& Galloway J.N. 1987. Chemistry of precipitation from a remote, terrestrial site in Australia. Journal of Geophysical Research-Atmospheres 92, 13299-13314, doi: 10.1029/JD092iD1 1p13299.

Lutjeharms J.R.E. \& Ansorge I.J. 2008. Oceanographic setting of the Prince Edward Islands. In S.L. Chown \& P.W. Froneman (eds.): The Prince Edward Islands: land-sea interactions in a changing ecosystem. Pp. 17-38. Stellenbosch: Sun Press.

Lyons W.B., Welch K.A., Welch S.A., Camacho A., Rochera C., Michaud L., Dewit R. \& Carey A.E. 2013. Geochemistry of streams from Byers Peninsula, Livingston Island. Antarctic Science 25, 181-190, doi: 10.1017/S0954102012000776.

McDougall I.A.N., Verwored W. \& Chevallier L.U.C. 2001. K-Ar geochronology of Marion Island, Southern Ocean. Geological Magazine 138, 1-17, doi: 10.1017/ S0016756801005039.

McNeil V.H., Cox M.E. \& Preda M. 2005. Assessment of chemical water types and their spatial variation using multi-stage cluster analysis, Queensland, Australia. Journal of Hydrology 310, 181-200, doi: 10.1016/j.jhydrol.2004.12.014.

Meurk C.D., Foggo M.N., Thomson B.M., Bathurst E.T.J. \& Crompton M.B. 1994. Ion-rich precipitation and vegetation pattern on Subantarctic Campbell Island. Artic and Alpine Research 23, 281-289, doi: 10.1080/00040851.199 4.12003067.

Neal C. \& Kirchner J.W. 2000. Sodium and chloride levels in rainfall, mist, streamwater and groundwater at the Plynlimon catchments, mid-Wales: inferences on hydrological and chemical controls. Hydrology and Earth System Sciences Discussions 4, 295-310.

Neal C., Reynolds B., Rowland P., Norris D., Kirchner J.W., Neal M., Sleep D., Lawlor A., Woods C., Thacker S. \& Guyatt H. 2012. High-frequency water quality time series in precipitation and streamflow: from fragmentary signals to scientific challenge. Science of the Total Environment 434, 3-12, doi: 10.1016/j.scitotenv.2011.10.072.

Nędzarek A., Tórz A. \& Podlasińska J. 2015. Ionic composition of terrestrial surface waters in maritime Antarctic and the processes involved in formation. Antarctic Science 27, 150-161, doi: 10.1017/S0954102014000522.

Nel W. 2012. A preliminary synoptic assessment of soil frost on Marion Island and the possible consequences of climate change in a maritime sub-Antarctic environment. Polar Research 31, article no. 17626, doi: 10.3402/polar. v3li0.17626.

Nel W., Boelhouwers J.C. \& Zilindile M.B. 2009. The effect of synoptic scale weather systems on sub-surface soil temperaturesin a diurnalfrost environment: preliminary observations from sub-Antarctic Marion Island. Geografiska Annaler Series A 91, 313-319, doi: 10.1111/j.1468-0459.2009.00372.x.

R Development Core Team 2016. R: a language and environment for statistical computing. Vienna: R Foundation for Statistical Computing.

Rouault M., Melice J.-L., Reason C.J.C. \& Lutjeharms J.R.E. 2005. Climate variability at Marion Island, Southern Ocean, since 1960. Journal of Geophysical Research-Oceans 110, c05007, doi: 10.1029/2004JC002492.

Schulze B.R. 1971. The climate of Marion Island. In E.M. Van Zinderen Bakker et al. (eds.): Marion and Prince Edward Islands. Report on the South African biological and geological expedition 1965-1966. Pp. 16-31. Cape Town: A.A. Balkema.

Smith V.R. 1987. Chemical composition of precipitation at Marion Island (sub-Antarctic). Atmospheric Environment 21, 1159-1165, doi: 10.1016/0004-6981(87)90243-5.

Smith V.R. 2008. Terrestrial and freshwater primary production and nutrient cycling. In S.L. Chown \& P.W. Froneman (eds.): The Prince Edward Islands: land-sea interactions in a changing ecosystem. Pp. 181-214. Stellenbosch: Sun Press. 
Smith V.R. \& Froneman W.P. 2008. Nutrient dynamics in the vicinity of the Prince Edward Islands. In S.L. Chown \& P.W. Froneman (eds.): The Prince Edward Islands: land-sea interactions in a changing ecosystem. Pp. 165-179. Stellenbosch: Sun Press.

Soulsby C. 1995. Influence of sea salt on stream water chemistry in an upland afforested catchment. Hydrological Processes 9, 183-196, doi: 10.1002/hyp.3360090205.

Stein A.F., Draxler R.R., Rolph G.D., Stunder B.J., Cohen M.D. \& Ngan F. 2015. NOAA's HYSPLIT atmospheric transport and dispersion modeling system. Bulletin of the American Meteorological Society 96, 2059-2077, doi: 10.1175/ BAMS-D-14-00110.1.

Stowe M.-J., Harris C.J.C., Hedding D.W., Eckardt F. \& Nel W. 2018. Hydrogen and oxygen isotope composition of precipitation and stream water on sub-Antarctic Marion Island. Antarctic Science 30, 83-92, doi: 10.1017/ S0954102017000475.

Taylor F.J. 1974. Chemical analyses of Campbell Island fresh waters. New Zealand Journal of Marine and Freshwater Research 8, 389-402, doi: 10.1080/00288330.1974.9515513.

Tomlinson M.S. \& De Carlo E.H. 2003. The need for high resolution time series data to characterize Hawaiian Streams. Journal of the American Water Resources Association 39, 113-123, doi: 10.1111/j.1752-1688.2003.tb01565.x.

Toro M., Camacho A., Rochera C., Rico E., Bañón M., Fernández-Valiente E., Marco E., Justel A., Avendaño
M.C., Ariosa Y. \& Vincent W.F. 2007. Limnological characteristics of the freshwater ecosystems of Byers Peninsula, Livingston Island, in maritime Antarctica. Polar Biology 30, 635-649, doi: 10.1007/s00300-006-0223-5.

Tyler P.A. 1972. Reconnaissance limnology of sub-Antarctic Islands. I. Chemistry of lake waters from Macquarie Island and the Iles Kerguelen. Internationale Revue der gesamten Hydrobiologie und Hydrographie 57, 759-778, doi: 10.1002/ iroh.19720570505.

Tyson P.D. \& Preston-Whyte R.A. 2000. The weather and climate of Southern Africa. Cape Town: Oxford University Press.

Van Staden W. 2011. Limnoecology of the freshwater algal genera (excluding diatoms) on Marion Island (sub-Antarctic). MSc dissertation, North-West University, Potchefstroom, South Africa.

Vinocur A. \& Unrein F. 2000. Typology of lentic water bodies at Potter Peninsula (King George Island, Antarctica) based on physical-chemical characteristics and phytoplankton communities. Polar Biology 23, 858-870, doi: 10.1007/ s003000000165.

Vowinckel E. 1954. Synotische Klimotologie vom gebiet Marion Island. (Synoptic climatology of the Marion Island area.) Notos 3, 12-21.

Welch K.A., Lyons W.B., Whisner C., Gardner C.B., Gooseff M.N., McKnight D.M. \& Priscu J.M. 2010. Spatial variations in the geochemistry of glacial meltwater streams in the Taylor Valley, Antarctica. Antarctic Science 22, 662-672, doi: 10.1017/S0954102010000702. 